\title{
Phytochemical Screening and Quantitative Determination of Phytochemicals in Leaf Extracts of Hannoa undulata
}

\author{
Longbap, B.D ${ }^{1}$, Ushie, O A ${ }^{\mathbf{1}^{*}}$, Ogah, E. ${ }^{1}$, Kendenson, A. $\mathrm{C}^{\mathbf{2}}$, Nyikyaa, J. $\mathrm{T}^{\mathbf{1}}$ \\ ${ }^{I}$ Department of Chemical Science, Federal University Wukari Nigeria \\ ${ }^{2}$ Department of Chemical Science, Federal University Kashere, Nigeria
}

*Corresponding Author: Ushie, O A, Department of Chemical Science, Federal University Wukari Nigeria

\begin{abstract}
Preliminary phytochemical screening on the dried leaf extracts of Hannoaundulata using cold maceration by serial exhaustive extraction method with solvents of increasing polarity (Hexane, chloroform, ethylacetate, acetone and ethanol) was investigated. The phytochemical screening of the crude leaf extracts revealed the presence of alkaloids, flavonoids, phenols, saponins and glycosides in all extracts. Quantitative analysis on some detected phytochemicals reveals high content of saponins $(1.033 \% / \mathrm{g})$, followed by flavonoids $(0.77 \% / g)$ and alkaloids $(0.72 \% / g)$.
\end{abstract}

Keywords: Phytochemical screening, Hannoaundulata, Polarity, cold maceration, leaf extracts

\section{INTRODUCTION}

Medicinal plants form an important component of flora and are widely distributed in the world. The pharmacological evaluation of substances from plants is an established method for the identification of lead compounds which can result to the development of novel and safe medicinal agents. Medicinal plants are composed of some certain organic compounds called phytochemicals which produce definite physiological actions in the human body and these bioactive substances include but are not limited to tannins, alkaloids, terpenoids, steroids and flavonoids (Edoega et al., 2005). The development of pharmaceutical products necessitates an exhaustive investigation of medicinal plants to improve our knowledge about their biological activities and the phytoconstituents responsible for them (Jothy et al., 2012). Furthermore, the need for comprehensive investigations in this area is more evident owing to the fact that only a limited number of medicinal plant species have received complete scientific inspection (Mazumder et al., 2008).

Hannoaundulata belongs to the family simaroubaceae. Hannoaundulata is locally known as "Gbur" in the Tiv dialect of Benue State (Shomkegh et al., 2016). It is used as a cure for various ailments in this area. Air dried roots bark are used for treating stomach ache and the bark and leaves for jaundice and malaria. The leaves are very coriaceous (leathery), obovate and are narrowed or cuneate at the base. It is a fast growing plant and usually grows up to 6-8 meters tall. It has a woody bark that is longitudinally fissured. Prot and Kornprobst reported in 1985 that quassinoid fractions extracted from the seeds of $H$. undulataprevented the penetration of juveniles of meloidogynejavanicainto tomato roots. According to the report, full inhibition of penetration occurred during three days of continuous exposure to a $5 \mathrm{ppm}$ quassinoid solution in the soil water. Quassinoids are highly oxygenated triterpenes which have attracted much attention because of their wide spectrum of biological activities.

\section{Materials ANd Methods}

\subsection{Sample Collection and Preparation}

The leaves of Hannoa undulata were collected from its natural habitat in Wukari local Government area of Taraba state, Nigeria. The samples were air dried and pulverized into a coarse powder. This was to increase the surface area to facilitate extraction.

\subsection{Extraction}

Cold maceration was used in the extraction by serial exhaustive extraction method which involves successive extraction with solvents of increasing polarity (n-hexane, chloroform, ethylacetate, acetone 
and ethanol).The extracts of the leaves were prepared by soaking $200 \mathrm{~g}$ of the coarsely powdered leaves in n-hexane in a stoppered container for a defined period (4 days) with frequent agitation. The resulting mixture was filtered and concentrated using rotary evaporator. The procedure was repeated on the residues using chloroform, ethyl acetate, acetone and ethanol sequentially in order of polarity. The extracts were kept in the refrigerator until required for analysis.

\subsection{Phytochemical Screening}

Preliminary phytochemical screening was carried out on all the crude leaf extracts (hexane, chloroform, ethyl acetate, acetone and ethanol) of Hannoaundulata using standard procedures as described by Trease and Evans (1989), Sofowora (1993), Ushie et al.,2016) and Santhi et al.,2016).

\subsection{Detection of Alkaloids}

Extracts were dissolved individually in dilute hydrochloric acid and filtered. The filtrates were used to test the presence of alkaloids.

\subsection{Mayer's Test}

Filtrates were treated with Mayer's reagent. Formation of a yellow cream precipitate indicates the presence of alkaloids.

\subsection{Wagner's Test}

Filtrates were treated with Wagner's reagent. Formation of brown/ reddish brown precipitate indicates the presence of alkaloids.

\subsection{Detection of Flavonoids}

\subsubsection{Lead Acetate Test}

Extracts were treated with few drops of lead acetate solution. Formation of yellow color precipitate indicates the presence of flavonoids.

\subsubsection{Alkaline Test}

Extracts were treated with few drops of dilute sodium hydroxide solution. Formation of a yellow color, which turned colorless on addition of dilute acid, indicated the presence of flavonoids.

\subsubsection{Detection of Steroids}

$2 \mathrm{~mL}$ of acetic anhydride was added to $0.5 \mathrm{~mL}$ of each extract in a test tube, followed by the addition of $2 \mathrm{~mL}$ of sulfuric acid. A color change from violet to blue or green indicated the presence of steroids.

\subsection{Detection of Phlobatannins}

$2 \mathrm{~mL}$ of each extract of the plant sample was boiled with $1 \%$ aqueous hydrochloric acid. Disposition of red precipitate indicated the presence of phlobatannins.

\subsection{Detection of Anthraquinones}

\subsubsection{Borntrager s Test}

$0.5 \mathrm{~mL}$ of each extract was boiled with $2 \mathrm{~mL}$ of $10 \% \mathrm{HCl}$ for few minutes in a water bath. The resultant solution was filtered and allowed to cool. Equal volume of chloroform was added to the filtrate. Few drops of $10 \% \mathrm{NH}_{3}$ solution was added to the mixture and heated. Formation of rose pink color indicated the presence of anthraquinones in the extracts.

\subsection{Detection of Terpenoids}

\subsubsection{Salkowski s Test}

$0.5 \mathrm{~mL}$ of each extract was mixed with $2 \mathrm{~mL}$ of chloroform, and $3 \mathrm{~mL}$ of concentrated $\mathrm{H}_{2} \mathrm{SO}_{4}$ was carefully added to form a layer. An appearance of a reddish brown color interface indicated the presence of terpenoids.

\subsection{Detection of Phenols}

\subsubsection{Ferric Chloride Test}

$10 \mathrm{~mL}$ of each extract was treated with few drops of ferric chloride solution. Formation of bluish black color indicates the presence of phenol. 


\subsection{Detection of Glycosides}

\section{Glycoside Test}

$0.5 \mathrm{~mL}$ of each extract was dissolved in $1 \mathrm{~mL}$ of water and then aqueous $\mathrm{NaOH}$ solution was added. Formation of yellow color indicates the presence of glycosides.

\subsection{Detection of Tannins}

$1 \mathrm{~mL}$ of each of the extracts was mixed with water and heated on a water bath. The mixture was filtered and ferric chloride was added to the filtrate. Formation of a dark green color indicated the presence of tannins.

\subsection{Detection of Saponins}

Foam Test

$1 \mathrm{~mL}$ of each of the extracts was shaken with $5 \mathrm{~mL}$ of distilled water. Formation of stable persistent foam indicated the presence of saponins.

\section{Quantitative Phytochemical Analysis}

The phytochemicals detected in the extracts of Hannoaundulata were quantified using standard procedures as described by Harborne (1973), Obdoni and Ochuko (2001), Krishnaiah et al., 2009) and Sathya et al., 2013).

\section{Estimation of Alkaloids}

Determination of alkaloids was done by using Harborne (1973) method. To $5 \mathrm{~g}$ of the sample, $200 \mathrm{~mL}$ of $10 \%$ acetic acid in ethanol was added and covered and allowed to stand for $4 \mathrm{~h}$. It was filtered and the filtrate was concentrated on a water bath to one quarter of the original volume. Concentrated $\mathrm{NH}_{4} \mathrm{OH}$ was added drop wise to the filtrate until precipitation was complete. The whole solution was allowed to settle and the precipitate was collected and washed with dilute $\mathrm{NH}_{4} \mathrm{OH}$ and then filtered. The residue is the alkaloid, which was dried and weighed.

\section{Estimation of Flavonoids}

$10 \mathrm{~g}$ of plant sample was repeatedly extracted with $100 \mathrm{~mL}$ of $80 \%$ aqueous methanol at room temperature. The whole solution was filtered through a Whatman No.42 filter paper into a pre weighed $250 \mathrm{~mL}$ beaker. The filtrate was transferred into a water bath and allowed to evaporate to dryness and weighed (Krishnaiahet al., 2009).

\section{Estimation of Total Saponins}

The method used was that of Obdoni and Ochuko (2001). To $20 \mathrm{~g}$ of the ground sample, $100 \mathrm{~mL}$ of $20 \%$ aqueous ethanol was added. The samples were heated over a hot water bath for $4 \mathrm{~h}$ with continuous stirring at about $55^{\circ} \mathrm{C}$. The mixture was filtered and the residue re-extracted with another $200 \mathrm{~mL} 20 \%$ ethanol. The combined extracts were reduced to $40 \mathrm{~mL}$ over water bath at about $90^{\circ} \mathrm{C}$. The concentrate was transferred into a $250 \mathrm{~mL}$ separation funnel and $20 \mathrm{~mL}$ of diethyl ether was added and shaked vigorously. The aqueous layer was recovered while the ether layer was discarded.

The purification process was repeated. $60 \mathrm{~mL}$ of n-butanol was added. The combined n-butanol extracts were washed twice with $10 \mathrm{~mL}$ of $5 \%$ aqueous sodium chloride. The remaining solution was heated in a water bath for evaporation and were further dried in the oven to a constant weight; the saponin content was calculated.

\section{RESUlts}

\subsection{Preliminary Phytochemical Screening of Leaves Extracts of Hannoaundulata}

The extracts (hexane, chloroform, ethyl acetate, acetone and ethanol) of the leaves of Hannoaundulata were screened for the presence of some phytochemicals. Table 1 presents the results of phytochemical screening of crude leaf extracts of Hannoaundulata. 
Table1. Preliminary Phytochemical Screening of the Various crude Leaf Extracts of Hannoaundulata.

\begin{tabular}{|c|c|c|c|c|c|c|c|}
\hline $\mathrm{S} / \mathrm{N}$ & Name of test & Test applied/Reagent used & $\mathrm{HE}$ & $\mathrm{CE}$ & EAE & $\mathrm{AE}$ & $\mathrm{EE}$ \\
\hline 1 & Alkaloids & $\begin{array}{l}\text { Mayer's reagent } \\
\text { Wagner's reagent }\end{array}$ & $\begin{array}{l}- \\
+ \\
\end{array}$ & $\begin{array}{l}- \\
+\end{array}$ & $\begin{array}{l}+ \\
+ \\
+\end{array}$ & $\begin{array}{l}+ \\
+ \\
\end{array}$ & $\begin{array}{l}+ \\
+ \\
\end{array}$ \\
\hline 2 & Flavonoids & $\begin{array}{l}\text { Lead acetate test } \\
\text { Alkaline reagent test }\end{array}$ & $\begin{array}{l}+ \\
+ \\
\end{array}$ & $\begin{array}{l}+ \\
+\end{array}$ & $\begin{array}{l}+ \\
+\end{array}$ & $\begin{array}{l}+ \\
+\end{array}$ & $\begin{array}{l}+ \\
+ \\
\end{array}$ \\
\hline 3 & Terpenoids & Salkowski test & - & - & - & - & + \\
\hline 4 & Phenols & Ferric chloride test & + & + & + & + & + \\
\hline 5 & Steroids & Extract + acetic anhydride $+\mathrm{H}_{2} \mathrm{SO}_{4}$ & + & + & + & + & - \\
\hline 6 & Saponins & Foam test & + & + & + & + & + \\
\hline 7 & Tannins & Ferric chloride test & - & - & + & + & + \\
\hline 8 & Anthraquinones & Borntrager's test & - & + & - & - & - \\
\hline 9 & Glycosides & Extract $+\mathrm{H}_{2} \mathrm{O}+\mathrm{NaOH}$ & + & + & + & + & + \\
\hline 10 & Phlobatannins & Extract $+1 \% \mathrm{HCl}+$ heat & - & - & - & - & + \\
\hline
\end{tabular}

Key: $H E=$ hexane extract, $C E=$ chloroform extract, $E A E=$ ethylacetate extract, $A E=$ acetone extract, EE= ethanol extract,$(+)=$ Present,$(-)=$ Absent

\subsection{Quantitative Analysis of Some Detected Phytochemicals}

The result of quantitative Phytochemical analysis is presented in Table 2 below.

Table2. Quantitative Phytochemical Analysis of Hannoaundulata

\begin{tabular}{|l|l|l|l|l|}
\hline S/N & Test Phytochemical & Weight of sample $(\mathrm{g})$ & Weight of dried filtrate $(\mathrm{g})$ & \% Crude calculated \\
\hline 1 & Flavonoids & 10.00 & 0.77 & 7.70 \\
\hline 2 & Alkaloids & 5.00 & 0.18 & 3.60 \\
\hline 3 & Saponins & 20.00 & 4.13 & 20.65 \\
\hline
\end{tabular}

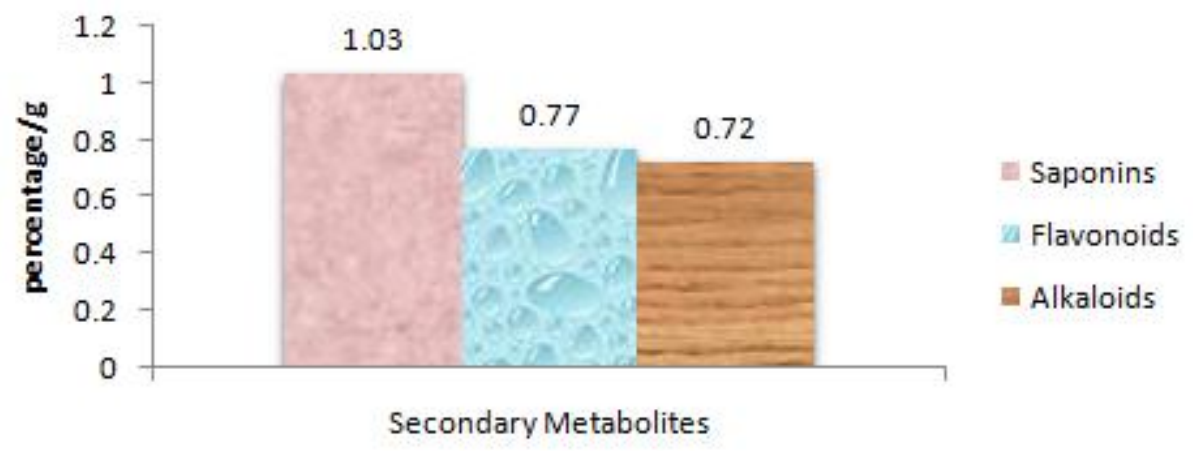

Figure1. Histogram for Quantification of Secondary Metabolites of Hannoaundulata

\section{DISCUSSION}

Hannoaundulatais used as traditional medicine in different parts of Nigeria. The present study was conducted on preliminary phytochemical and quantitative analysis of the leaf extracts of the plant.

\subsection{Preliminary Phytochemical Analysis}

The phytochemical analysis of the hexane, chloroform, ethyl acetate, acetone and ethanol extract of the leaves of Hannoaundulata revealed the presence of anthraquinones, steroids, terpenoids and terpenes, phlobatannins, phenols, saponins, tannins, flavonoids, glycosides and alkaloids.

The results obtained revealed the absence of anthraquinones in hexane, ethyl acetate, ethanol and acetone extracts. However, this substance was found to be present in chloroform extract. Tannins were present in all extracts except hexane and chloroform extracts. Phlobatannins were absent in all the extracts except ethanol extract. Steroids were present in all extracts except ethanol extract. Terpenoid was absent in all extracts exceptin ethanol extract. Phenols, alkaloids, saponins, flavonoids and glycosides were found to be present in all extracts as shown in Table 1. Quantitative analysis carried out on three detected phytochemicals; alkaloids, flavonoids and saponinsreveals that these secondary metabolites are present in different amount in the leaves of the plant (Table 2). Amongst the quantified phytochemicals, Saponin content of the leaves of $H$. undulata was found to be $1.033 \%$ 
/g followed by flavonoid $0.77 \% / \mathrm{g}$ and then alkaloid which was found to be $0.72 \% / \mathrm{g}$. Therapeutically, Saponins are very important as they are shown to have hypolipidemic and anticancer activity. The natural anti-cancer agent saponin reacts with cholesterol rich plasma membrane of various cancer cells and arrests their proliferation (Raoet al., 1995). This high level of saponin present in the leaves of Hannoaundulata indicates that the plant can be used to produce anti-cancer drugs. Alkaloids and flavonoids contribute various medicinal properties such as analgesic, antioxidant and astringent activity (Chung et al., 1998).

These classes of phytochemical compounds are known to show therapeutic activity against several bacteria and it is not surprising that these plant extracts are used traditionally by herbalist to cure bacteria related ill-health (Njoku and Obi, 2009).

Hannoaundulatacan be used as anti-inflammatory, antispasmodic, anti-cancer and analgesic agent. This is attributed to the presence of flavonoids, alkaloids, steroids, glycosides and saponins in their compositions (Savithrammaet al., 2011). Saponins are precursors of important therapeutic drugs such as cortisone and contraceptive estrogens (Kareruet al., 2008). There is tremendous, commercially driven promotion of saponins as dietary supplements and nutriceuticals (Ushieet al., 2016). Saponins are a mild detergent used in intracellular histochemistry staining to allow antibody access to intracellular proteins. The saponins are used in hypercholestrolaemia, hyperglycemia, antioxidant, anticancer, anti-inflammatory activity and weight loss (Manickamet al., 2014). Saponin are also known to cause complexation with cholesterol to form pores in cell membrane bilayers, e.g., in red cell (erythrocyte) membranes, where complexation leads to red cell lysis (hemolysis) on intravenous injection (Francis et al.; 2002).Hannoaundulata can be used as an analgesic, anaesthetic and as social drugs in view of the fact that it contains alkaloids. The alkaloids contained in plants are used in medicine as anaesthetic agents (Herouratet al., 1988). Harborne (1988) also reported on the analgesic properties of alkaloids. Alkaloids has contributed to the majority of the poisons, neurotoxins and traditional psychedelics and social drugs [e.g. nicotine, caffeine, methamphetamine (ephedrine) cocaine, and opiates] consumed by humans (Zenk and Juenger, 2007). Flavoniods were detected in all the extract. According to Okoli and Okere (2010), flavonoids are potent water soluble super antioxidants and free radical scavengers which prevent oxidative cell damage, have strong anticancer activity and inhibit tumor growth. The beneficial effects of fruit, vegetables, and tea or even red wine have been attributed to flavonoid compounds rather than to known nutrients and vitamins (Félicien, 2008).Hannoaundulatais important in pharmacy because it contains steroidal compounds. Okwu (2001) reported that steroidal compounds are of importance and interest in pharmacy due to their relationship with sex hormones. They are known to effect the development and control of the reproductive tract in humans and molt insects. Other function includes inducing sexual reproduction in aquatic fungi (Ushie et al., 2016). Hannoaundulata can be used as an anti-inflammatory, antiseptic, antioxidant agent due to the presence of tannins. De Bruyne et al., (1999) reported that in medicine, especially in Asian (Japanese and Chinese) natural healing, tannin-containing plant extracts are used as astringents, against diarrhoea, as diuretics, against stomach and duodenal tumours and as antiinflammatory, antiseptic, antioxidant and haemostatic pharmaceuticals (Dolaraet al., 2005). Saxenaet al., (2013) pointed out that recently, tannins have attracted scientific interest, especially due to the increased incidence of deadly illnesses such as acquired immune deficiency syndrome (AIDS) and various cancers (Blyttet al., 1988). Pharmacologically, glycosides have been found to be useful in treatment of several illnesses for instance cardiac glycoside have long been employed as important ingredient for arrow poisons and drugs (Trease and Evans 1989). The presence of terpenoids that have carboxylic acid groups could also be responsible for the activity of the organic extracts of Hannoaundulata (Njoku and Obi 2009). Langenheim, 1994 and Dudareva, 2004 also reported that terpenoids have medicinal properties such as anti-carcinogenic (e.g. perilla alcohol), anti-malarial (e.g. artemisinin), anti-ulcer, hepaticidal, antimicrobial or diuretic (e.g. glycyrrhizin) activity. Anthraquinones are extensively applied in medicine. In the pharmaceutical industry, the natural and synthetic derivatives of 9, 10 anthraquinone are beneficial to mammals and humans as they can display antibacterial, antitrypanosomal and antineoplastic activities (Heyman et al., 2009; Taruset al., 2002; Velez-Cruz and Osheroff, 2004). Phlobatannins have been reported for its wound healing properties. They also have anti-inflammatory and analgesic (Ayindeet al., 2007) and anti-oxidant properties (Okwu et al., 2004) 


\section{REFERENCES}

Ayinde B.A, Omogbai E.K, Amaechina F.C (2007). Pharmacognosy and hypotensive evaluation of Fiscus exasperate vahi(Moraceae) leaf. Acta Pol Pharm 64:543-546.

Blytt H.J, Guscar T.K and Butler L.G (1988). Anti-nutritional effects and ecological significance of dietary condensed tannins may not be due to binding and inhibiting digestive enzymes. Journal of Chemical Ecology, 14: 1455-1465.

Chung K.T, Wong T.Y, Wei C.L, Huang Y.W, Lin Y (1998). Tannins and human health: a review. Criti. Rev. Food. Sci. Nutri.,421-64.

De Bruyne T, Pieters L, Deelstra H, Vlietinck A (1999). Condensed vegetables tannins: biodiversity in structure and biological activities. Biochemical System Ecology; 27: 445-59.

Dolara P, Luceri C, De Filippo C, Femia A.P, Giovannelli L, Carderni G, Cecchini C, Silvi S,

Orpianesi C, Cresci A (2005). Red wine polyphenols influence carcinogenesis, intestinal microflora, oxidative damage and gene expression profiles of colonic mucosa in F344 rats. Mutation Research; 591: $237-46$.

Dudareva N and Pichersky E (2000). Biochemical and molecular genetics aspects of floral scent. Plant Physiology 122 (3): 627-633.

Edeoga H.O, Okwu D.E, Mbaebie B.O (2005). Phytochemical constituents of some Nigerian medicinal plants. A'fr.J. Biotechnol., 4(7): 685-688.

Evans W.C and Trease G.E (2009).Pharmacognosy.16th ed.Edinburgh, UK pp 353-415.

Félicien Breton (2008). Health benefits of oligomeric proanthocyanidins. http://www.frenchscout.com/polyph enols\#procyanidins.

Francis G, Zohar K, Harinder P, Makkar S and Klaus B (2002). The biological action of saponins in animal systems: a review. British journal of Nutrition 88(6): 587-605.

Harbone J.B (1973). Phytochemical methods. London. Chapman andHall, Ltd., 49-188.

Harborne J.B (1988): Introduction to Ecological Biochemistry.3rd edition. Academic Press, London.10-15.

Herourat D, Sangwin R.S, Finiaux M.A, Sangwan-Norrel B.S (1988).Variationsin the leaf alkaloid content of androgenicdiploid plants of Daturuinnoxia, Planta medical J. Med. Plant Res.54:14-20.

Heyman H.M, Hussein A.A, Meyer J.J, Lall N (2009). Antibacterial activity of South African medicinal plants against methicillin resistant Staphylococcus aureus. Pharm. Biol., 47: 67-71.

Jothy S.L, Torey A, Darah I, Choong Y.S, Saravanan D, Chen Y, Latha L.Y, Deivanai S; Sasidharan S (2012).Cassia spectabilis: A promising traditional herb in health improvement. Molecules (17) 6:1029210305.

Kareru P.G, Keriko J.M, Gachanja A.N, and Kenji G.M (2008). Direct Detection of Triterpenoid Saponins in Medicinal Plants.Afr J Tradit Complement Altern Med.; 5(1): 56-60

Krishnaiah D.T, Devi A, Bono and Sarbatly R (2009). Studies on phytochemical constituents of six Malaysian medicinal plants. J. Med. Plants. Res. 3(2): 67-72.

Langenheim J.H(1994). Higher plant terpenoids: A phytocentric overview of their ecological roles. Journal of Chemical Ecology; 20: 1223- 1280.

ManickamMurugan and VeerabahuRamasamy Mohan (2014). Phytochemical, FT-IR and antibacterial activity of whole plant extract of Aervalanata(L.) Juss. Ex. Schult. J. of Med. Plants Studies, 2(3): 51-57.

Mazumder P.M, Percha V, Farswan M, Upaganlawar (2008). A. Cassia: A wonder gift to medical sciences. Int. J. Clin. Pharm., 17(1): 16-38.

Njoku O.V and Obi C (2009). Phytochemical constituents of some selected medicinal Plants. African Journal of Pure and Applied Chemistry Vol. 3 (11), pp. 228-233

Obdoni B.O, Ochuko P.O (2001). Phytochemical studies and comparative efficacy of the crude extracts of some Homostatic plants in Edo and Delta States of Nigeria. Global J. Pure Appl. Sci. 8 b:203-208.

Okoli B.J, Okere O.S (2010). Antimicrobial Activity of the phytochemical constituents of Chrysphyllumalbidum G.Don-Holl (African star apple) plant.Journal of Research in National development.8(1):356.

Okwu D.E (2001). Evaluation of the chemical composition of indigenous spices and flavourong Agents. Global J of Pure Appl.Sci.7(3): 455-459

Okwu D.E, Okwu M E (2004). Chemical composition of Spondiasmombinlinn. Plant parts. J SustAgric Environ 6: $140-147$.

Prot Jean-Claude and Kornprobst Jean-Michel (1985). Effects of quassinoids extracted from Hannoaundulata seed on the penetration and reproduction of Meloidogynejavanicaon tomato. Revue Nématol., 8 (4) : 383 389 
Rao A.V, Sung M.K (1995).Saponins as anticarcinogens. J Nnutrition., 717S-724S.

Santhi K and Sengottuvel R(2015). Qualitative and Quantitative Phytochemical analysis of Moringaconcanensis Nimmo Int. J. Curr. Microbiol. App. Sci., 5(1): 633-640

Sathya, V., Bharathidasan, R., Tamil, S.S., Solphia, R.N., Hakkiya, R \&Prabakaran, M. (2013). Quantitative, phytochemical analysis and in vitro antibacterial activity of Bauchiniatomatosa, L. Journal of Natural Product Resources, 3(2),31-33.

Saxena J, Rajeev N, Dharmendra S and Abhishek Gupta (2013).Phytochemistry of Medicinal Plants.Journal of Pharmacognosy and Phytochemistry1(6),168

Savithramma N.M, LingaRao and BeenaPrabha (2011). Phytochemical Studies of Dysophyllamyosuroides (Roth.) Benth. In. Wall. And Talinumcuneifolium(Vahl.) Willd.Research Journal of Phytochemistry, 5: 163-169

Shomkegh S.A, Mbakwe R and Dagba B.I (2016).Utilization of Wild Plants for Medicinal Purposes in Selected Tiv Communities of Benue State, Nigeria:AnEthnobotanical Approach, European Journal of Medicinal Plants 14(4): 1-14

Sofowora, A. (1993) Medicinal Plants and Traditional Medcines Africa, Spectrum Books Ibadan

Tarus P.K, Machocho A.K, Langat T.C, Chhabra S.C (2002). Flavonoids from Tephrosia aequilata. Phytochem., 60: 375-379.

Trease G.E and Evans W.C (1989).Pharmacognsy(13th ed) Baillere.Tindall London pp176-180.

Ushie O.A, Egwaikhide P.A, and Longbap B.D (2016).Phytochemical Screening and Antimicrobial Activity of Tamarindusindica,IJTCM; Vol. 1(2): 0010-0017

Ushie O.A, Onen A.I, Ugbogu O.C, Neji P.A and Olumide V.B (2016).Phytochemical Screening and Antimicrobial Activities of Leaf Extracts of Swieteniamacrophylla. Chem Search Journal 7(2): $64-69$

Velez C, Osheroff N (2004). DNA topoisomerases: type II, in: Encyclopedia of Biological Chemistry, Elsevier Inc., pp. 806-811.

Zenk M.H, Juenger M (2007). Evolution and current status of the phytochemistry of nitrogenous compounds. Phytochemistry.68: 2757-72

Citation: Longbap, B.D et al., "Phytochemical Screening and Quantitative Determination of Phytochemicals in Leaf Extracts of Hannoa undulata", International Journal of Medicinal Plants and Natural Products (IJMPNP), vol. 4, no. 2, pp. 32-38, 2018. http://dx.doi.org/10.20431/2454-7999.0402005

Copyright: (0) 2018 Authors. This is an open-access article distributed under the terms of the Creative Commons Attribution License, which permits unrestricted use, distribution, and reproduction in any medium, provided the original author and source are credited. 